\title{
THE ETHICS OF DEUTERONOMY: AN EXEGETICAL AND THEOLOGICAL STUDY ${ }^{1}$
}

J.G. Millar

The introduction reviews recent work in OT ethics, highlighting the persistent methodological confusion. The discussion points out the importance of distinguishing between the related tasks of describing, synthesising and applying the ethics of the OT. Deuteronomy is proposed as a case study in description and synthesis, and an appropriate method developed. The implications of the outcome of this study for the possibility of speaking of a coherent ethical 'system' within the OT as a whole are examined.

The discussion of the form of Deuteronomy in Chapter 1 focuses on the significance of parallels with ANE Treaties. The ethical and rhetorical function of the covenant metaphor is considered. It is concluded that the structure highlights that Israel is a people constantly facing decisions as a consequence of their covenantal relationship with Yahweh. A study of the patriarchal promise tradition in the book shows that it is exploited to make this same point. The land is used as an ethical device, proclaiming both Yahweh's grace and Israel's responsibility. This reciprocity is shown to be a fundamental part of the rhetoric of the book. The selective rehearsal of recent history supports the view that Israel's relationship with Yahweh demands decision. Discussion of the parenetic vocabulary (including the 'number change' phenomenon) in Deuteronomy underlines the fact that the call to decision pervades every part of the book.

In the second Chapter, it is demonstrated that ideas of time and place dominate the framework of Deuteronomy. The

1J.B. Miller, The Ethics of Deuteronomy: An Exegetical and Theological Study of the Book of Deuteronomy (Unpublished D.Phil. Thesis, University of Oxford, 1995); supervisor: Professor John Barton. 
importance of the journey metaphor in the book is pointed out. Chapters 1-3 are shown to be central to the theological agenda of the book, introducing a journey beginning in Horeb in the wake of the Exodus and moving to Kadesh Barnes. Kadesh is presented as the archetypal place of rebellion. The journey in the wilderness becomes the journey to the land, with the victories in Transjordan acting as a paradigm for the conquest to follow. Moab becomes the place of renewed opportunity, a new Kadesh. The development of this idea is traced in Deuteronomy 4, where the revelation at Moab is equated with that at Horeb and the journey motif extended to provide a metaphor for the entire ethical history of Israel. The day of decision at Moab is shown to recapitulate the days of decision of the past and anticipate those in the future. This is achieved by a deliberate conflation of generations, where the people at Moab are addressed as if they have experienced both the past and future of Israel. It is proposed that this careful use of time and place has the effect of binding ethics to revelation, thus defining the nature of the decision facing Israel.

The development of these concepts becomes clear with the introduction of the Decalogue in chapter 5. It is argued that chapters 6-11 build on this, showing how Moab holds the key to entry, occupation and eventually return to the land.

A study of the themes of time and place in the concluding chapters of the book reveal a concern for future days of decision for Israel in the land. The first of these is shown to be the day at Shechem, where blessings define the ideal of relationship with Yahweh in the land and curses threaten return to 'Egypt'. The growing preoccupation with the future is revealed by the juxtaposition of the decision at Moab with the need for and effects of future divine intervention in chapters 29-30. 'It is argued that, along with chapters 31-34, this material reflects a continuing interest in the idea of the ethical journey of Israel.

Chapter 3 discusses the laws of chapters 12-26. It is proposed that the laws in general and the 'centralisation laws' in particular should be read in the context of the framework. The journey of Israel is shown to inform the role of the place chosen by Yahweh, and the whole collection is set in the 
context of the specifics of the decision demanded by Yahweh. After the importance of ANE legal techniques for reading biblical law is pointed out, a brief discussion of the relationship of the laws in Deuteronomy to the Book of the Covenant and the Holiness Code is offered. Recent suggestions that the Deuteronomist has presented the laws in a carefully arranged Decalogue order are examined, prior to a detailed exegesis of the laws.

The exegesis of chapters 12-26 reveals a high level of coherence. Similarities to the Decalogue are highlighted, but attempts to discern a rigid order are seen to break down. It is argued that the Deuteronomist's concerns centre on the proper worship of Yahweh and Israel's enjoyment of relationship with him, pre-eminently at the sanctuary. The diverse statutes of chapters $17-25$ are interpreted in the light of $16: 18-20$ as promoting right relationships in Israel as the prerequisite of enjoyment of Yahweh in his land. The ethical and theological distinctives of these laws are shown to be inseparable. The summarising role of chapter 26, linking the ideas of journey, enjoyment and initiative response, is examined, as is its contribution to the ethical coherence of the laws and the framework.

The context in which the decision spelled out in the laws is to be made is considered in Chapter 4. A study of the role of the nations in Deuteronomy reveals that a careful distinction is made between the occupants of the land and those beyond its borders. The latter are depicted as the audience to the decisions Israel must make. Evidence is put forward the divine activity and concern for these nations. This international awareness, it is argued, is accompanied by a subtle framing of the laws on the war of conquest revealing their exceptional nature. The 'ban' is interpreted as a theological device underlining the necessity of complete repudiation of the ways of the nations, rather than a military advance on other pentateuchal material. The inclusion of conquest legislation in a section aimed to delimit unnecessary killing is pointed out. This is taken to imply the recognition of the character of war as an ethical difficulty, only justified by the command of Yahweh. 
The final chapter traces the growing suspicion in the book that Israel is a victim of her nature and will inevitably fail. This subtext is shown to be apparent from the opening chapters, where the journey of Israel to the land is narrated in highly ironic terms. The proclamation of the potential of life in the land is constantly accompanied by reminders of the frailty of Israel. It is demonstrated thata chapters 4-11 betray a deeprooted ambivalence regarding the future of Israel, which is not removed by the laws. An ominous note sounded by the length and nature of the curses at Shechem is shown to give way to the Deuteronomist's own answer to the questions handing over the future of Israel in chapters 29-30. This answer, is in itself, revealed to be profoundly ambiguous. It is argued that the need for future, transforming intervention is affirmed, but in such a way as to enhance the Deuteronomic preaching rather than emasculate it. The narration of Moses' Song and record of his death near a $p$ lace of apostasy on this understanding do nothing to remove the note of pessimism. The study shows that the book ultimately gives no direct answer to the question 'Can Israel obey?'. This produces an even greater sense of the significance of the perpetual decision facing Israel in her relationship with Yahweh.

In conclusion, it is affirmed that ethics in Deuteronomy are based on the response to Yahweh's gracious initiatives demanded of Israel. The key contention is that Israel's enjoyment of life in the land given by Yahweh depends on the decision to conform to the preaching of Moses at Moab, at Shechem and on into the land. It is suggested that this rationale is consistently evident throughout both the framework and the laws. This shows that it is reasonable to speak of the ethics of Deuteronomy and to articulate this ethical perspective relatively simply. The implication is drawn that a similar approach may enable the description and synthesis of the ethics of other books, facilitating comparison and a coherent expression of the ethics of the Old Testament as a whole. 